\title{
REPRESENTACIONES DE LA CIUDAD MODERNA EN LAS OBRAS DE ROBERTO ARLT Y MÁRIO DE ANDRADE
}

\author{
Volker Jaeckel*
}

\begin{abstract}
Resumen: Buenos Aires y San Pablo son dos ciudades que se transformaron en símbolos de la modernidad en América Latina. Las dos ciudades ejercen una atracción especial sobre los autores de los movimientos de vanguardia del siglo XX. En las décadas de los años 1920 y 1930, las dos metrópolis atravesaban un profundo proceso de transformación social, y al mismo tiempo lograron la afirmación como principales centros de cultura y de intelectualidad del continente sudamericano. En el presente trabajo se pretende establecer una comparación de la experiencia urbana en su modelación literaria de dos autores: Roberto Arlt y Mário de Andrade.
\end{abstract}

Palabras-clave: Modernidad; Buenos Aires; San Pablo; literatura urbana; años 1920.

\section{Introducción}

En los años 1920 del siglo XX Buenos Aires y San Pablo sufren cambios muy profundos en su arquitectura, economía, sociedad y cultura, que marcan la llegada de la modernidad a las

* Universidade Federal de Minas Gerais. 
capitales del hemisferio sur. La relación entre literatura y experiencia urbana queda más visible, cuando la gran ciudad, transformada por la revolución industrial, surge como el fenómeno determinante de la vida humana. Esto sucede tanto en Europa, como en América Latina. Vilém Flusser y Nestor Canclini desarrollaron teorías antropológicas, analizando la ciudad en este contexto temporal y espacial, mientras Ingenschay la abarca como un intertexto semiótico, dando preferencia al análisis de la mirada periférica sobre la urbe. Buenos Aires y San Pablo ejercen una atracción especial sobre los autores de los movimientos de vanguardia del siglo XX. En el presente trabajo se pretende establecer una comparación de la experiencia urbana en su modelación literaria de dos autores: Roberto Arlt y Mário de Andrade. En las décadas de los años 1920 y 1930, las dos metrópolis atravesaban un profundo proceso de transformación social, y al mismo tiempo lograron la afirmación como principales centros de cultura y de intelectualidad del continente sudamericano.

\section{Buenos Aires y San Pablo}

Buenos Aires era la ciudad portuaria que recibió en aquella época el mayor número de inmigrantes de Europa y de otras partes del mundo. Con su llegada cambió automáticamente el carácter y el aspecto visual de la ciudad, que aumentó su áreahacia el oeste y hacia el sur. El automóvil y la luz eléctrica llegaron a las calles. Las primeras fábricas iniciaron la producción industrial en la capital porteña. Gracias al gran auge de las exportaciones que pasaban por el puerto, entre las cuales merece ser mencionada la exportación a gran escala de carne bovina, la ciudad comenzó una fase de cierta prosperidad económica.

De la noche a la mañana tuvieron lugar evoluciones sociales repentinos e inesperados: el número de hombres jóvenes superaba considerablemente al de mujeres, lo cual provocó una proliferación del alcohol, las drogas, la violencia y la prostitución. 
En los años 1920 surge un submundo en torno al comercio de mujeres y a la prostitución, que se organiza bajo el comando de jóvenes inmigrantes sin recursos financieros.

La llegada en masa de inmigrantes también tiene influencia en la vida cultural de Buenos Aires, ya que se intenta imitar los modelos europeos de moda, cine, teatro, música, restaurantes, hasta incluso del ámbito deportivo. ${ }^{1}$ También en la arquitectura se anhela copiar los rascacielos norteamericanos y europeos, ensanchando las avenidas tradicionales de ciudad durante las reformas urbanísticas.

San Pablo, una ciudad provinciana de tamaño mediano habitada por plantadores de café y trabajadores inmigrantes, pasó a convertirse en pocos años en la metrópoli más importante de Brasil. En 1920 la ciudad tenía alrededor de 580.000 habitantes. Río de Janeiro todavía continuaba siendo el centro intelectual y cultural de Brasil, si bien la fama de ser una urbe febril e inquieta, industrializada y habitada por diferentes pueblos y razas, con una urbanización híbrida y una codicia por el progreso, era de San Pablo. Ésta se transformó en el símbolo que expresaría mejor que cualquier otra ciudad los valores de "brasilidade" y modernidad, la dicotomía entre tradición y vanguardia, al mismo tiempo, y, por lo tanto encarnaba la llegada de la época moderna en toda su ambigüedad.

\section{Tentativa de una aproximación teórica a laciudad periférica moderna}

Para Richard Morse las urbes periféricas de América Latina pierden hasta 1880 sus características de ciudades patricias y se transforman en ciudades burguesas. Hasta el final de la década de los años 1920 ya muestran un perfil de ciudades masificadas.

${ }^{1}$ TA. Von den Städten des Realen zu den Städten des Imaginären, p. 111. 
Como consecuencia de la dinámica del modernismo y de la propia región, estas urbes habían sufrido una transición a verdaderas arenas culturales. Morse denomina el fenómeno de "la irrupción modernista de la década de 1920"y destaca entre las ciudades latinoamericanas símbolos de este movimiento: en primer lugar San Pablo y después Buenos Aires. ${ }^{2}$

Según el filósofo checo Vilém Flusser, San Pablo solamente puede ser considerada ciudad con algunas restricciones, porque engloba la síntesis de los tres ambientes tradicionales, esenciales para una ciudad antigua, como es el caso de su natal Praga: el espacio privado, el espacio político y el espacio sacro. Para Flusser la formación de la capital paulista surge en torno a un espacio económico y en función de actividades predominantemente comerciales. Flusser afirma que las ciudades de Brasil, al contrario de las europeas, no se fundan o desarrollan en el entorno de un roble o de una iglesia, sino en las cercanías de una fábrica de zapatos o de un Shopping y, por lo tanto, obedecen a un concepto racional y no a una idea mítica de fundación. ${ }^{3}$

Nestor Canclini ve la ciudad periférica latinoamericana no solamente como un lugar para habitar, sino como un lugar para la imaginación, ya que está siendo representada a través de imágenes en las novelas, las canciones, las películas, los relatos de la prensa, la radio y televisión. Los espacios urbanos también están hechos para viajar por ellos y estos viajes son objeto del estudio de la antropología visual:

La antropología, que buscó entender la relación con lo distinto explorando continentes lejanos, encuentra también en las ciudades multiculturales de occidente, el choque súbito e intrigante con otros modos de

\footnotetext{
${ }^{2}$ MORSE. As cidades "periféricas" como arenas culturales: Rússia, Áustria, América Latina, p. 206.

${ }^{3}$ FLUSSER. Brasilien oder die Suche nach dem neuen Menschen, p. 262.
} 
vida. La simple expansión de los transportes por la trama urbana, las interacciones violentas que provocan, pueden compararse con la irrupción de la modernidad en poblaciones "primitivas". ${ }^{4}$

Dieter Ingenschay distingue tres miradas periféricas diferentes sobre la ciudad. Las novelas de Roberto Arlt y Mário de Andrade pueden ser atribuidas a la tercera categoría que el profesor alemán llama "la venganza de los marginalizados y la intención incipiente de desmaterializar" el espacio urbano. ${ }^{5}$

En los años 1920 del siglo pasado surge en Brasil y Argentina un paradigma diferente del discurso urbano. Este es el resultado de la conciencia de una identidad propia y periférica, como expresión de la alteridad. Mientras Jorge Luis Borges intenta imitar enfáticamente en su lírica los tradicionales discursos topológicos sobre Madrid, Roma, Paris o Londres, aparecen nuevas estéticas de literatura metropolitana, cuyos representantes más innovadores son Roberto Arlt y Mário de Andrade. Años después encontramos sus continuadores en José Agustín en México, Ignacio Loyola Brandão en Brasil y Ricardo Piglia en Argentina, autores que articulan su rechazo al eurocentrismo, a través de su deconstrucción y de una nueva valoración de la periferia en el contexto de las teorías de dependencia.

\section{Modernidad y vanguardia en la América Latina}

Si bien no es el objetivo principal de este trabajo, no podemos dejar de mencionar la dicotomía que se percibe en

\footnotetext{
${ }^{4}$ CANCLINI. Ciudades imaginarias, p. 108.

${ }^{5}$ INGENSCHAY. Großstadtaneignung in der Perspektive des "peripheren Blicks", p. 12.
} 
diversas obras de Mário de Andrade $^{6}$ y de otros modernistas latinoamericanos. Por un lado, como parte de los nuevos movimientos literario-artísticos, demuestran una cierta proximidad a los expresionistas alemanes, a los futuristas italianos u otras vanguardias europeas. Por otro, se manifiesta también una aproximación a la cultura popular e indígena. Los años 1920 fueron, por tanto, uno de los períodos más propicios para un estudio comparativo de las artes y de la literatura en América Latina. Sin duda alguna, desde el Manifiesto antropófago y la legendaria Semana de Arte Moderna en 1922, las tentativas deinvertir los conceptos culturales de centro y periferia ganaron espacio en todo el continente sudamericano.

El fenómeno de la modernidad proyecta sus sombras sobre la creación literaria de los diversos países latinoamericanos desde el inicio del siglo veinte. La ciudad grande, la metrópoli no se revela solamente como lugar de encuentro de los jóvenes poetas, sino que también despierta sus ansiedades y deseos, de tal forma, que provoca una repercusión directa y palpable en sus producciones literarias.

Las vanguardias latinoamericanas, concretamente las argentinas y las brasileñas, constituyen corrientes dialécticas entre el nacionalismo y el cosmopolitismo, entre la ruptura y la continuidad. Son movimientos que descubren la ciudad como un espacio de confluencia discursiva y de mezcla cultural, como afirma Viviane Gelado. ${ }^{7}$

\footnotetext{
${ }^{6}$ Veáse el capitulo sobre la valorización de lo popular en la época de las vanguardias históricas en la América Latina, en: GELADO. Poéticas da transgressão: vanguarda e cultura popular nos anos 20 na América Latina, p. 63-85. MAILHE. Un viaje por los pliegues del sujeto. JAECKEL. A percepção da grande cidade na obra de Georg Heym e Mário de Andrade.

${ }^{7}$ GELADO. Poéticas da transgressão: vanguarda e cultura popular nos anos 20 na América Latina, p. 31.
} 
Debido a los rápidos cambios socioculturales, económicos y tecnológicos, la ciudad ejerce una fascinación especial sobre los artistas y los intelectuales. Llega a ser la representación de lo moderno y de la modernidad. Según Beatriz Sarlo:

(...) modernidad, modernización y ciudad aparecen entremezcladas con nociones descriptivas, como valores, como espacios físicos y procesos materiales e ideológicos. En la medida en que Buenos Aires se altera, ante los ojos de sus habitantes, con una aceleraciónque pertenece al ritmo de las nuevas tecnologías de producción y transporte, la ciudad es pensada como condensación simbólica y material del cambio. ${ }^{8}$

La ciudad proporciona lugares para la transacción de valores culturales, estéticos y éticos diferentes y constituye el escenario, en el cual se articulan diversos conflictos de intereses como en un gran teatro de una cultura compleja.

A consideração da cidade como espaço de mescla cultural com que Beatriz Sarlo alude à Buenos Aires pós-aluvião imigratório, na década de vinte, poderia aludir, certamente com ressalvas, a São Paulo (política e economicamente hegemônica na União, sobretudo a partir de 1920) e à Cidade de México posterior à Revolução. A Cidade configura-se como espaço da heterogeneidade social e discursiva. Assim no âmbito das produções concretas, é evidente a elaboração de um discurso literário mais próximo

\footnotetext{
${ }^{8}$ Sarlo apud TA. Von den Städten des Realen zu den Städten des Imaginären. Entwicklungstendenzen im hispanoamerikanischen Stadtroman des 20. Jahrhunderts, p. 113. Véase también al respecto de la modernidad de Buenos Aires también SARLO. Una modernidad periférica. Buenos Aires 1920 y 1930, p. 13-29.
} 
dos atos de fala que da língua concebida com um corpus abstrato (...). ${ }^{9}$

Por lo tanto, se trata aquí de una investigación comparativa de discursos literarios similares a la lengua hablada, rasgos característicos del estilo de Roberto Arlt y de Mário de Andrade que retratan la alienación del hombre en la ciudad grande, creando héroes simbólicos con un carácter paradigmático. Estos protagonistas novelescos, por su alteridad social o cultural, con su lenguaje típico del mundo marginalizado forman el elemento clave de esta comparación entre los autores que publicaron sus obras más importantes a finales de los años 1920.

\section{Roberto Arlt (1900 -1942)}

Roberto Arlt nació en 1900 como hijo de padre alemán y madre italiana en el barrio porteño de Flores, donde pasó su infancia en circunstancias precarias. El ambiente familiar era de una familia de la clase media-baja de los inmigrantes que llegaron recientemente a la capital argentina con muchas esperanzas y poco dinero.

Roberto Arlt tuvo que empezar muy pronto a ganarse la vida y a ayudar a sustentar a su familia. Fue conocido como periodista de varios periódicos bonaerenses, por sus reportajes de sección policial y sobre todo por sus Aguafuertes que salieron regularmente desde 1928 hasta 1942 en los periódicos Crítica y El Mundo. Su mayoría está dedicada a la ciudad de Buenos Aires, los llamados Aguafuertes porteñas, que constituyen una crítica a las costumbres, una sátira general de los ciudadanos y abarcan las consecuencias nefastas de industrialización y modernización, como por ejemplo, la precariedad de las viviendas en los

\footnotetext{
${ }^{9}$ GELADO. Poéticas da transgressão: vanguarda e cultura popular nos anos 20
} na América Latina, p. 31. 
conventillos y la falta de empleo. Son esfuerzos por analizar el comportamiento del proletariado lumpen y de la clase media y transmiten las impresiones de los cafés, fiestas, espectáculos populares y de los medios de transporte en un estilo semejante al de los costumbristas decimonónicos.

Los Agua fuertes pueden ser considerados como retratos instantáneos de la vida cotidiana urbana contemporánea, enel sentido de que "seu registro dialogava, no suporte do jornal com o uso que então estava começando a se dar à fotografia: entendida como instantâneo e não mais como pose". ${ }^{10}$

Arlt llega a través de la lectura de escritores rusos a los expresionistas alemanes. Se evidencia la semejanza de los títulos Los siete locos con una narración de Andreiev Los siete aborcados. Existen muchos rasgos en común entre la obra de Dostoievski, los expresionistas alemanes y Roberto Arlt. Todos utilizan una mezcla entre lo absurdo, lo auténtico, lo alegórico, lo simbólico y lo real, y muestran claras tendencias antiburguesas con una cierta inclinación por los marginales, los locos, criminales y prostitutas, son poetas que exaltan lo feo, lo repugnante, lo que llaman los expresionistas de "abyecto". ${ }^{11}$

Uno de los temas preferidos por los expresionistas era la ciudad grande, la nueva Babilonia. No es una mera coincidencia el hecho de que fuese justamente en los años 1920 del siglo pasado cuando se publicaron en los diversos lugares del mundo las primeras novelas urbanas, sin existir ninguna relación entre sus autores (Alfred Döblin: Berlin Alexanderplatz, John dos Passos: Manbattan Transfer y las novelas de Arlt).

La ciudad y las masas urbanas se transforman en un arquetipo de la modernidad, un tema ya abarcado por los expresionistas y todavía más por los alemanes Walter Benjamin,

${ }^{10}$ GELADO. A poética expressionista na narrativa de Roberto Arlt, p. 113.

${ }^{11}$ Sobre lo abyecto en obras de poetas expresionistas véase JAECKEL. A percepção da grande cidade na obra de Georg Heym e Mário de Andrade, p. 8. 
Siegfried Kracauer y Franz Hessel que articularon "un aspecto típico de la sociabilidad urbana moderna: La flânerie, el caminar solo y sin rumbo, entre las muchedumbres por las calles de ciudad". ${ }^{12}$ Arlt, como Benjamin, asiduo lector de Baudelaire se revela en sus Aguafuertes y novelas como un flâneur que quiere encontrar la metrópoli de su proyección imaginaria en sus andanzas por el agitado centro de Buenos Aires con su ajetreo de urbe moderna.

\section{Eljuguete rabioso (1926)}

La publicación de la primera novela de Arlt significaba el inicio de la novela urbana argentina y el fin del predominio de la novela rural o novela de la tierra con temáticas gauchescas. El juguete rabioso se encuentra en la tradición de la novela picaresca española y se divide en cuatro episodios relativamente independientes que narran las aventuras y peripecias de un pícaro porteño con el nombre Silvio Astier.

En el primer capítulo con el título Los ladrones, así como en el tercero, el protagonista y narrador en primera persona, Silvio, se encuentra en constante movimiento, deambulando por las calles de la capital. En sus largos paseos, percibe la ciudad como una fuerza vital y dinámica desde la perspectiva del peatón. En estilo picaresco participa de la vida cotidiana en las calles, cafés, tiendas y ferias y relata sus observaciones de forma realista y algunas veces conayuda de sátiras.

La crítica social de Arlt se manifiesta claramente en el discurso narrativo, cuando se hace evidente el proceso del desarrollo psíquico y moral del protagonista, las miserables condiciones de las viviendas en los llamados conventillos y la falta de perspectiva de vida para un joven. El claro contraste entre los diferentes tipos de morada muestra la contradicción entre la

\footnotetext{
${ }^{12}$ SEBRELI. Cosmópolis y modernidad en Roberto Arlt, p. 92.
} 
fachada brillante y el lado oculto, adverso de la vida en la metrópoli. ${ }^{13}$ Después de la decepción por ser expulsado de la escuela militar, el protagonista vaga por la ciudad sin orientación, reflexionando sobre su destino en una ciudad hostil que se conspiró contra sus propósitos y ambiciones.

Ahora cruzaba las calles de Buenos Aires, con estos gritos adentrados en el alma.- iCuando mamá lo sepa! - (...) Calor de fiebre me subía a las sienes; ódiame sudoroso, tenia la sensación de que mi rostro se había entosquecido de pena, deformado de pena, de una pena hondísima, toda clamorosa. Rodaba abstraído, sin derrotero. Por momentos los ímpetus de cólera me envaraban los nervios, quería gritar, luchar a golpes con la ciudad espantosamente sorda... y súbitamente todo se me rompía adentro, todo me pregonaba a las orejas mi absoluta inutilidad. - ¿Que será de mí? ${ }^{14}$

El pícaro de Arlt comete varias tentativas de huida de la ciudad (salida en barco, suicidio con revolver) que siempre fracasan por motivos distintos. Se trata de un motivo común en la literatura urbana que evidencia la relación ambivalente entre individuo y ciudad. En el último capítulo tituladoJudas Iscariote, Silvio Astier trabaja como representante de una papelería en varios barrios que forman evidentemente un contraste social conlos de la burguesía que son tantas veces retratados por Borges en sus poesías y cuentos.

Por las chatas calles del arrabal, miserables y sucias, inundadas del sol, con cajones de basura en las puertas, con mujeres ventrudas, despeinadas y escuálidas hablando en los umbrales y llamando a sus

${ }^{13}$ WENZEL. Der Buenos Aires-Roman, p. 73-74.

${ }^{14}$ ARLT. El juguete rabioso, p. 85. 
perros o a sus hijos, bajo a el arco de cielo más límpido y diáfano, conservo el recuerdo fresco, alto y hermoso. ${ }^{15}$

De forma muy parecida a la de los expresionistas, Arlt utiliza los contrastes, aquí entre el cielo claro y límpido y la miseria de los barrios humildes Caballito, Flores, Vélez Sásfield y Villa Crespo para patentizar que Silvio Astier logra superar el pesimismo que se había adueñado de su vida.

Silvio es el héroe que madura psicológica y físicamente a lo largo de la historia, porque en cada capítulo aprende algo nuevo sobre la vida en la ciudad grande. Por ello, se puede hablar de un tipo de novela de aprendizaje o Bildungsroman urbano, aunque la condición social de Silvio le impide encontrar a su amor, lo que muchas veces es un tema importante en este tipo de literatura. Al final de este proceso de formación, Astier delata a su compañero de otros tiempos, Rengo, para evitar un crimen, en el cual participaría por invitación del compinche que confiaba a Silvio hasta el más mínimo detalle.

\section{Los siete locos (1929)}

La acción de la segunda novela de Roberto Arlt se concentra en pocos días y noches del mes de agosto de 1929. Los personajes actúan principalmente en un Buenos Aires nocturno o de madrugada.

En esta novela la ciudad pasa de ser únicamente el lugar de la acción y se transforma en el objeto central de la narración. Arlt contrapone las concepciones utópicas de la "sociedad secreta "a la sociedad concreta de Buenos Aires. Los ambientes están formados por la pequeña burguesía, la clase obrera y el submundo. Corresponden a las fantasías apocalípticas de la

${ }^{15}$ ARLT. El juguete rabioso, p. 105-106. 
metrópolis que ya fueron características del arte expresionista en Europa. Su retrato está marcado por el miedo existencialista y por lo absurdo de la existencia humana. Entre los personajes figuran hombres enfermos, locos, destruidos, pobres, violentos y llenos de miedo. Son prostitutas, rufianes, asesinos, inmigrantes, funcionarios públicos, comerciantes, inventores, anarquistas, adeptos a la astrología y a las ciencias ocultas. Todos los protagonistas de la novela son marginales de clases socialmente inferiores que son excluidos del mundo de los ricos. Las relaciones entre los seres humanos son predominantemente marcadas por agresiones, violencia y odio.

Al poner una mano en el bolsillo encontró que tenía
un puñado de billetes y entonces entró en el bar
japonés. Cocheros y rufianes hacían rueda en torno
de las mesas. Un negro con cuello palomita y
alpargatas negras se arrancaba los parásitos del
sobaco y tres "macrós"polacos, con gruesos anillos de
oro en los dedos, en su jerigonza, trataban de
prostíbulos y alcahuetas. En otro rincón varios
choferes de taxímetro jugaban a los naipes. ${ }^{16}$

Los bares decadentes reflejan el Buenos Aires contemporáneo de inmigrantes, rufianes y los viciados en el juego de azar. La fonda deteriorada crea una atmósfera siniestra y tenebrosa inclusive a plena luz del día. Los olores de la cocina provocan asco y acaban con el apetito. El tango es forma típica de expresión de las clases bajas de la sociedad porteña, siendo la articulación corporal del sufrimiento y de la melancolía que dominan el estado de ánimo de Erdosain. El protagonista de Arlt como las otras figuras no conocen el sentido de la vida, la frustración de su existencia desencadena barbaridades, acciones anormales, crímenes o huidas inútiles.

${ }^{16}$ ARLT. Los siete locos; Los lanzallamas, p. 23. 
El tango carcelario surgía plañidero de las cajas (...) el languor de la guitarra y del bandoneón, divinizando el sufrimiento de la puta y el horrible aburrimiento de la cárcel (...) el negro que le tocabael trasero al menor, ahora llevaba las manos de éste a sus partes pudendas, mientras un círculo de diarieros armaba un vocerío infernal y el patrón gigantesco cruzaba el salón con un plato de sopa en una mano y otro guiso rojo, para una comandita de dos rateros que devoraban en un rincón. ${ }^{17}$

El lenguaje de la novela varía mucho, del nivel culto hasta las manifestaciones muy vulgares y está lleno de expresiones provenientes del lunfardo, el habla típicamente popular de Buenos Aires que sirve obviamente para caracterizar el ambiente de los rufianes y jugadores profesionales del submundo. En el caso del lunfardo se trata de una hibridación de diversas peculiaridades lingüísticas llegadas de todas partes del mundo que son expresión del cosmopolitismo de la capital porteña. ${ }^{18}$

El otro Buenos Aires es el de los ricos y acomodados burgueses del Barrio Norte. Se trata de un mundo ideal e inalcanzable para Erdosain. Por lo que su descripción es de alguien que se encuentra en una perspectiva externa y aislada. El mundo de los ricos está marcado por la limpieza, el lujo y la protección, ellos viven una vida recluida y ajena a la dura realidad, marcada por la lucha por la vida. Erdosain se limita a ser observador de este mundo muy extraño, solamente describe las fachadas de las casas y mansiones majestuosas, pero nunca piensa en entrar. Al contrario que los barrios proletarios con apariencia gris, cenicienta y lúgubre, este de la gente rica y poderosa aparece en tonalidades de colores acogedoras, claras y suaves.

\footnotetext{
${ }^{17}$ ARLT. Los siete locos; Los lanzallamas, p. 195.

${ }^{18}$ SEBRELI. Cosmópolis y modernidad en Roberto Arlt, p. 88.
} 
Anduvo por las solitarias ochavas de las calles Arenales y Talcahuano, por las esquinas de Charcas y Rodríguez Peña, en los cruces de Montevideo y Avenida Quintana, apeteciendo el espectáculo de esas calles magníficas en arquitectura, y negadas para siempre a los desdichados. Sus pies, en las veredas blancas, hacían crujir las hojas caídas de los plátanos, y fijaba la mirada en los ovalados cristales de las grandes ventanas, azogados por la blancura de las cortinas interiores. Aquel era otro mundo dentro de la ciudad canalla que el conocía (...) Deteniéndose, observaba los garajes lujosos como patenas, y los verdes penachos de los cipreses en los jardines, defendidos por murallas de cornisas dentadas, $\mathrm{o}$ verjas capaces de detener el ímpetu de un león. ${ }^{19}$

En el contexto de la descripción de los barrios prósperos se muestra claramente la influencia de los medios de masas y de la literatura trivial sobre Arlt y sus personajes literarios, cuando se mezclan elementos del discurso de la novela sentimental de los años 1920 con las fantasías de una vida de gente rica del protagonista Erdosain que hoy le pueden parecer al lector estereotipos cursis. No podemos olvidar que en aquella época los medios de masa ya dominaban lo imaginario colectivo a través de la imprenta, de la literatura de folletín, de la propaganda, del cine y del tango y que contribuían significativamente para una percepción individual de la realidad urbana. ${ }^{20}$ Por lo tanto, la ficción penetra en la imaginación de la realidad de tal manera

\footnotetext{
${ }^{19}$ ARLT. Los siete locos; Los lanzallamas, p. 29.

${ }_{20}$ TA. Von den Städten des Realen zu den Städten des Imaginären. Entwicklungstendenzen im bispanoamerikanischen Stadtroman des 20. Jabrbunderts, p. 134-35 descubre estos fenómenos en Arlt, pero también su continuación de una forma similar en la novela La ciudad ausente de Ricardo Piglia y Gußmann. Der Reality-Text, en la novela brasileña de la actualidad.
} 
que se transforma en un modelo para la realidad y las acciones novelescas son repeticiones de las lecturas hechas por los personajes. ${ }^{21}$

La visión de la ciudad grande presentada en Los siete locos es sumamente pesimista, marcada por la brutalidad, la falta de perspectiva, sentimientos de amenaza y miedo, pero al mismo tiempo ejerce una cierta fascinación. La ciudad de Arlt tiene rasgos demoníacos, grotescos y absurdos, que son indudablemente propios de la temprana lírica expresionista y también de las obras de Alfred Döblin o del teatro esperpéntico de Ramón del ValleInclán. ${ }^{22}$

La historia de Erdosain encuentra su continuación en la novela Los Lanzallamas (1931), donde nuevamente Buenos Aires aparece como la enemiga del protagonista en una lucha que el héroe solamente puede ganar con la adaptación a las reglas del sistema social, si no quiere perecer aislado, desmoralizado y destruido por las angustias existenciales en la selva de la metrópoli. Los efectos de la alienación del individuo en la sociedad masificada dominan también esta segunda parte de la narración. La monstruosidad y el caos de la ciudad se hacen palpables con imágenes del ambiente industrial, de construcciones gigantes, de los últimos avances tecnológicos.

\section{Mário de Andrade (1893-1945)}

Mário de Andrade era poeta, novelista, crítico de artes, ensayista y musicólogo que tenía un gran impacto en la renovación literaria y artística de Brasil y pasó casi toda su vida en San Pablo. Andrade declara su pasión por esta ciudad en algunas de las

\footnotetext{
${ }^{21}$ TA. Von den Städten des Realen zu den Städten des Imaginären, p. 135.

${ }^{22}$ Véase JAECKEL. Reflejos de la Madrid moderna en la obra de Miguel de Unamuno, Ramón Gómez de la Serna y Ramón del Valle-Inclán.
} 
poesías que componen la Pauliceia Desvairada. Viajaba por muchas partes del país buscando la oportunidad de retratar en texto e imagen los elementos típicos de la cultura popular brasileña. En estas ocasiones escribe su diario del turista aprendiz que mantiene fuertes vínculos intertextuales con la novela Macunaíma. ${ }^{23}$

\section{Macunaíma (1928)}

La novela sobre "el héroe sin ningún carácter" no es lo que llamamos literatura urbana en sentido estricto de la palabra. No obstante, cabe aquí una breve comparación con las novelas de Arlt por varios motivos. Sin duda alguna, Macunaíma es la versión brasileña del pícaro, lo que sería llamado de "malandro" en portugués. Una parte significativa de la novela se desarrolla en San Pablo. Concretamente desde el capítulo IV, cuando el héroe inicia su viaje en busca del talismán que le fue robado por el gigante Venceslau Pietro Piedra que había huido para la capital paulista. Para recuperar este objeto cuenta con la ayuda de sus hermanos Manaape e Jiguê que llegan juntos a "cidade macota de São Paulo esparramada a beira-rio do igarapé Tietê". ${ }^{24}$

La primera noche en la ciudad se divierte con tres mujeres prostitutas las “cunhãs”, despierta al día siguiente y se encuentra con la mujer más seductora, intrigante y misteriosa que es la metrópoli moderna, muchas veces llamada de puta babilónica, devoradora de hombres:

De-manhãzinha ensinaram que todos aqueles piados berros cuquiadas sopros roncos esturros não eram nada disso não, eram mas cláxons campainhas apitos buzinas e tudo era máquina. As onças-pardas não

\footnotetext{
${ }^{23}$ MAILHE. Un viaje por los pliegues del sujeto, p. 4.

${ }^{24}$ ANDRADE. Macunaíma, p. 40.
} 
eram onças-pardas, se chamavam fordes hupmobiles chevrolés dodges mármons e eram máquinas. Os tamanduás os boitatás as inajás de curuatás de fumo, em vez eram caminhões bondes autobondes anúnciosluminosos relógios faróis rádios motocicletas telefones gorjetas postes chaminés... Eram máquinas e tudo na cidade era só máquina! O herói aprendendo calado. De vez em quando estremecia. ${ }^{25}$

El choque del protagonista después de su llegada dura una semana, durante la cual no come, no habla, no juega. El alejamiento de su espacio habitual obliga al protagonista a aprender y entender el mundo a su alrededor a través del sentido visual. La nueva percepción de las impresiones está condicionada a un ejercicio de recodificación del mundo externo. ${ }^{26}$ Macunaíma consigue reconquistar el talismán, el muiraquitã, y cumple su tarea después de varias tentativas fracasadas en forma de luchas quijotescas. El rescate del talismán se transforma en una tentativa de restablecer los lazos rotos por diversas pérdidas con el sexo femenino. ${ }^{27}$

La ciudad de San Pablo aparece desde el inicio como el lugar de las oportunidades, especialmente en lo que refiere al enriquecimiento económico, como si fuera una tierra prometida. La experiencia en la ciudad moderna aumenta aun más la falta de carácter del héroe. El espacio urbano presentado en la novela es un fiel reflejo de la imaginación del narrador y caracterizado por las peripecias vividas por el protagonista:

\footnotetext{
${ }^{25}$ ANDRADE. Macunaima, p. 41.

${ }^{26}$ MARTINS. A literatura da cidade grande: São Paulo através de Mário de Andrade e João Antônio.

${ }^{27}$ PONCIANO. Onde fica São Paulo?
} 
Cidade é belíssima, e grato o seu convívio. Toda cortada de ruas habilmente estreitas e tomadas por estátuas e lampiões graciosíssimos e de rara escultura; tudo diminuindo com astúcia o espaço de forma tal que nessas artérias não cabe a população. ${ }^{28}$

Diversas ironías y verdades sobre el ciudadano son introducidas en el texto a través de un lenguaje simbólico y metafórico, como sucede en esta cita proveniente de la carta a las Icamiabas:

São os paulistas gente ardida e avalentoada, e muito feita às agruras da guerra. Vivem em combates singulares e coletivos, todos armados da cabeça aos pés; assim assaz numerosos são os distúrbios por cá, em que, não raro, tombam na arena da luta, centenas de milhares de heróis, chamados bandeirantes. Pelo mesmo motivo São Paulo está dotada de mui aguerrida e vultosa Polícia, que habita palácios brancos de custosa engenharia. A essa Polícia compete ainda equilibrar os excessos da riqueza pública, por se não desvalorizar o oiro incontável da Nação. ${ }^{29}$

De una forma muy irónica, presenta los peligros inherentes a la ciudad y muestra claramente como la policía es factor indispensable en la vida urbana para controlar y reglamentar la convivencia de los hombres ciudadanos, que estando sin observación, entran rápidamente en conflictos violentos entre sí.

El personaje Macunaíma también contrae varias enfermedades provocadas por su permanencia en la ciudad grande, lo que puede ser entendido como expresión de lo maléfico de la ciudad. Son relatados 16 tipos diferentes, en su gran mayoría enfermedades venéreas, expresión de sufrimientos que la ciudad

\footnotetext{
${ }^{28}$ ANDRADE. Macunaíma, p. 84.

${ }^{29}$ ANDRADE. Macunaíma, p. 86.
} 
grande causó al héroe de la novela. Por otro lado, él lleva de la ciudad como trofeos el revolver, el reloj y las gallinas, como si hubiese dominado y subyugado la ciudad. Son representaciones de la violencia urbana, de la vida estresante marcada por el reloj y la convivencia de las masas urbanas en espacios diminutos y precarios.

Para Macunaíma, que en el momento de su llegada es un extranjero, un forastero, la ciudad no se revela maternal, como lo deseaba el héroe, y tampoco consigue dominarla. Ella no es capaz de devorarlo, sino lo devuelve para el lugar de origen. El encuentro entre los dos, el medir de fuerzas termina empatado.

Como Arlt, Mário de Andrade también era periodista y escribió entre 1920-21 crónicas publicadas en el periódico Ilustração Brasileira de Río de Janeiro con la finalidad de transmitir a los lectores brasileños sus impresiones de las mudanzas sorprendentes que estaban aconteciendo en la capital paulista con la llegada repentina de la modernidad. Sobre San Pablo, dice en la prim era crónica "é agressiva e misteriosa como os seus heróis; suas belezas recônditas; raro o estrangeiro que alcança levantar um pouco o pesado manto de segredo em que se embuça". ${ }^{30}$

\section{Conclusión}

El estudio de los textos en cuestión ha mostrado comola ciudad periférica de la América del Sur se ha transformado en los años 1920 repentinamente en un símbolo de la modernidad, un fenómeno que se hace patente con similar vehemencia en Europa, no obstante provocando un choque fulminante. Su llegada sorprendente a las ciudades grandes de Brasil y Argentina, afecta a los hombres desplazados, inmigrantes llegados del interior del

\footnotetext{
${ }^{30}$ ANDRADE. De São Paulo. Cinco Crônicas de Mário de Andrade 1920-21, p. 73.
} 
estado o de otros países, que todavía no logran entender su condición en la urbe moderna. Roberto Arlt y Mário de Andrade son los escritores que evidencian la alienación del hombre en la ciudad moderna, aunque bajo perspectivas muy diferentes. Los héroes de ambos son pícaros tradicionales que se encuentran al margen de la sociedad urbana y pretenden abandonarla.

En las figuras principales y en los ambientes donde están ubicadas las novelas de Arlt hallamos una semejanza con el Berlín de Alfred Döblin, tal como lo conocemos de su obra maestra Berlin Alexanderplatz, el llamado Scheunenviertel en las proximidades de la Rosenthaler Platz tiene muchos de los rasgos de los barrios porteños, por donde transitan Astier y Erdosain. Al contrario de su compatriota Borges, Arlt percibe y subraya los cambios negativos que la modernidad trae consigo para sus habitantes, como lo hicieron los poetas expresionistas alemanes que sintieron la ciudad grande como un Moloch que devoraba a los hombres de las metrópolis sin merced. Además podemos reflexionar sobre la hipótesis de que se hallen en Arlt ciertos ecos de la película Metropolis de Fritz Lang, cuya versión original sin cortes de la censura, fue encontrada, por casualidad, en Buenos Aires el año pasado. $^{31}$

\footnotetext{
${ }^{31}$ Véase el reportaje del día 5 de Julio de 2008 en $E l$ País con el título "Metrópolis" auténtica. Se trata de 25 minutos de filme que pertenecen a una copia llevada a Buenos Aires en 1928 por el director de una distribuidora argentina.
} 


\begin{abstract}
Resumo: Buenos Aires e São Paulo são duas cidades que se transformaram em símbolos da modernidade da América latina. As duas cidades exercem uma atração especial sobre os autores dos movimentos de vanguarda do século XX. Nas décadas dos anos 1929 e 1930 as duas metrópoles atravessavam um profundo processo de transformação social, e ao mesmo tempo alcançaram a afirmação como principais centros de cultura e intelectualidade do continente sul-americano. No presente trabalho pretende-se estabelecer uma comparação da experiência urbana em sua modelagem literária de dois autores: Roberto Arlt e Mário de Andrade.
\end{abstract}

Palavras-chave: Modernidade, Buenos Aires, São Paulo, Literatura urbana, América Latina, década de 1920.

\title{
REFERENCIAS
}

ARLT, Roberto. El juguete rabioso. Buenos Aires: Losada 1995.

ARLT, Roberto. Los siete locos; Los lanzallamas. Ed. crítica de Mario Goloboff, Madrid; Barcelona; La Habana; Lisboa; Paris; México; Buenos Aires; Lima; Guatemala; San José: ALLCA XX, 2000.

ANDRADE, Mário de. Macunaíma. O herói sem nenhum caráter. São Paulo: Círculo do livro, 1987.

ANDRADE, Mário de. De São Paulo. Cinco Crônicas de Mário de Andrade 1920-21. Telê Ancona Lopez (Org.). São Paulo: SENAC, 2004.

CANCLINI, Nestor. Ciudadesimaginarias. Buenos Aires: EUDEBA, 1999.

FLUSSER, Vilém. Brasilien oder die Suche nach dem neuen Menschen. Für eine Phänomenologie der Unterentwicklung. Mannheim: Bollmann, 1994.

GELADO, Viviane. Poéticas da transgressão: vanguarda e cultura popular nos anos 20 na América Latina. Rio de Janeiro: 7 Letras; São Carlos: EDUFSCar, 2006. 
GELADO, Viviane. A poética expressionista na narrativa de Roberto Arlt. Fragmentos, n. 32, p. 101-115, 2007.

GUSSMANN, Katja. Der Reality-Text. Brasilianische Großstadtliteratur im Zeitalter der technischen Bilder. Frankfurt: Vervuert, 2002.

INGENSCHAY, Dieter. Großstadtaneignung in der Perspektive des "peripheren Blicks". In: BUSCHMANN, Albrecht; INGENSCHAY, Dieter (Ed.). Die andere Stadt. Großstadtbilder in der Perspektive des peripheren Blicks. Würzburg: Königshausen \& Neumann, 2000. p. 7-19.

JAECKEL, Volker. A percepção da grande cidade na obra de Georg Heym e Mário de Andrade. Contingentia, v. 4. n. 1, p. 1-12, 2009. Disponible en: <http://www.seer.ufrgs.br/index.php/contingentia/ article/view/7107/4976>.

JAECKEL, Volker. Reflejos de la Madrid moderna en la obra de Miguel de Unamuno, Ramón Gómez de la Serna y Ramón del Valle-Inclán. In: MACCIUCI, Raquel (Ed.). Siglos XX y XXI. Memoria del I Congreso Internacional de Literatura y Cultura Españolas Contemporãneas. La Plata: Universidad Nacional de La Plata, 2008. Disponible en: < http:// congresoespanyola.fahce.unlp.edu.ar/programa/ponencias/ VolkerJaeckel.pdf>

MAILHE, Alejandra. Un viaje por los pliegues del sujeto. Del consumo a la aprehensión del "otro", en O turista aprendiz. Orbis Tertius, IX (10), 2004, 1-7. Disponible en: <http: www.orbistertius.ulp.edu.ar/ numeros/numero-10/03.\%Mailhe.pdf $>$.

MARTINS, Renata. A literatura da cidade grande: São Paulo através de Mário de Andrade e João Antônio. In: ARMBRUSTER, Claudius; SIEPMANN, Helmut (Ed.). Cruzando fronteiras na Lusofonia: Intermedialidade Intertextualidade Interculturalidade (enimprenta).

MORSE, Richard M. As cidades "periféricas" como arenas culturais: Rússia, Áustria, América Latina, en: Estudos Históricos, v. 8, n. 16, p. 205-225, 1995

PONCIANO, William Junior. Onde fica São Paulo? No coração e na devoração de Macunaíma. Nau Literária, n. 4, jan./jun. 2007.

SARLO, Beatriz. Una modernidad periférica. Buenos Aires 1920 y 1930. Buenos Aires: Nueva Visión, 1988. 
SEBRELI, Juan José: Cosmópolis y modernidad en Roberto Arlt. Cuadernos Hispanoamericanos, n. 661-662, p. 85-100, 2005.

TA, Beatrix. Von den Städten des Realen zu den Städten des Imaginären. Entwicklungstendenzen im bispanoamerikanischen Stadtroman des 20. Jabrbunderts. München: Meidenbauer, 2007.

WENZEL, Bettina. Der Buenos Aires-Roman. Die Literarisierung der Großstadterfabrung bei zeitgenössischen argentinischen Schriftstellern. Frankfurt/Berlin/Bern/New York/Paris/Wien: Peter Lang, 1999.

Recebido para publicação em 31 de janeiro de 2010 Aprovado em 29 de junho de 2010 